\title{
RANCANG BANGUN ALAT PENDETEKSI KONDISI TELUR AYAM BERBASIS MIKROKONTROLER ATMEGA 32 DENGAN SENSOR CAHAYA
}

\author{
Afdal Tahir ${ }^{1}$, Mery Subito², Agustinus Kali $^{3}$ \\ ${ }^{1)}$ Mahasiswa Teknik Elektro Universitas Tadulako, \\ ${ }^{2,3)}$ Dosen Teknik Elektro Universitas Tadulako \\ Program Studi S1 Teknik Elektro, Fakultas Teknik, Universitas Tadulako \\ E-mail : afdal.tahir21@gmail.com
}

\begin{abstract}
When consumers buy eggs, consumers should be more careful choosing the egg because there are some eggs that the quality has been decreased or the eggs are damaged and cannot be consumed anymore. This is caused by the length of egg storage time and didn't have a tool that capable to detect the condition of the egg. People or egg breeders / entrepreneurs habit on looking the quality of eggs still use manual way, as a result it takes a long time because it must select the eggs condition one by one. The purpose of this research is to design and make the detection tool of chicken egg condition with ATmega 32 microcontroller using light sensor, so that the time efficiency and the result of egg selection becomes faster. . The use of tools is very easy and simple so that consumers or breeders / entrepreneurs can use it. Then to simplify and speed up the selection time of chicken eggs breeder or entrepreneur to distinguish good and damaged egg condition.
\end{abstract}

Keywords: Egg Detection, ATmega32, LDR, Arduino Uno

\section{PENDAHULUAN}

Pada saat para konsumen membeli telur, konsumen harus lebih teliti memilih karena ada beberapa telur yang telah menurun kualitasnya atau telur tersebut rusak dan tidak dapat dikonsumsi lagi. Hal ini disebabkan oleh lama waktu penyimpanan dan tidak adanya alat yang mampu mendeteksi kondisi telur tersebut. Kebiasaan masyarakat ataupun peternak/pengusaha telur dalam melihat kualitas telur masih menggunakan cara manual akibatnya memerlukan waktu yang cukup lama karena harus menyeleksi kondisi telur satu persatu.

Dari permasalahan di atas, perlu dibuatkan suatu alat yang dapat mendeteksi kondisi telur, yang prinsip kerjanya hampir sama dengan cara manual yaitu dengan cara meneropong telur menggunakan sinar matahari, tetapi alat pendeteksi kondisi telur ini menggunakan sensor LDR (Light Dependent Resistor), sejenis resistor yang resistansinya akan berubah seiring dengan perubahan intensitas cahaya yang diterima. Variabel yang digunakan pada penelitian ini adalah nilai resistansinya untuk mengetahui kondisi telur yang masih baik ataupun telur yang telah mengalami penurunan kualitas atau telah rusak. Kemudian, alat ini juga memiliki tombol untuk menentukan jenis telur yang akan di uji dan ada penambahan voice processor sebagai output suara untuk memudahkan pengguna buta huruf.

\section{LANDASAN TEORI}

A. Mikrokontroler ATmega 32

Mikrokontroler AVR ATmega32 merupakan CMOS dengan konsumsi daya rendah, mempunyai 8-bit proses data (CPU) berdasarkan arsitektur AVR RISC. Dengan mengeksekusi instruksi dalam satu (siklus) clock tunggal, ATmega32 memiliki kecepatan data rata-rata (throughputs) mendekati 1 MIPS per MHz, yang memungkinkan perancang sistem dapat mengoptimalkan konsumsi daya dan kecepatan pemrosesan.[1]

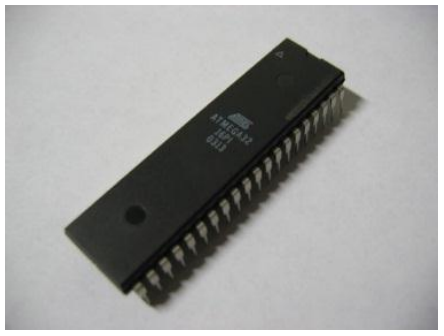

Gambar 1. Bentuk fisik ATmega 32 


\section{B. Arduino Uno}

Arduino Uno adalah sebuah board mikrokontroller yang berbasis ATmega328. Arduino memiliki 14 pin input/output yang mana 6 pin dapat digunakan sebagai output PWM, 6 analog input, crystal osilator $16 \mathrm{MHz}$, koneksi USB, jack power, kepala ICSP, dan tombol reset. Arduino mampu men-support mikrokontroller; dapat dikoneksikan dengan komputer menggunakan kabel USB.[2]

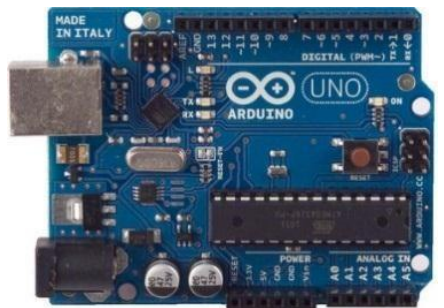

Gambar 2. Bentuk fisik Arduino Uno

\section{Analog To Digital Converter (ADC)}

Analog to Digital Converter adalah salah satu fasilitas mikrokontroler ATmega 32 yang berfungsi untuk mengubah data analog menjadi data digital. ADC memiliki 2 karakter prinsip, yaitu kecepatan sampling dan resolusi. Kecepatan sampling suatu ADC menyatakan seberapa sering

sinyal analog dikonversikan ke bentuksinyal digital pada selang waktu tertentu. Kecepatan sampling biasanya dinyatakan dalam sample per second (SPS).[3]

\section{Light Dependent Resistor (LDR)}

Light Dependent Resistor adalah sebuah komponen elektronika yang termasuk ke dalam jenis resistor yang nilai resistansinya (nilai tahanannya) akan berubah apabila intensitas cahaya yang diserap juga berubah. Dengan demikian LDR juga merupakan resistor yang mempunyai koefisien temperature negative, dimana resistansinya dipengaruhi oleh intrensitas cahaya. LDR terbuat dari Cadium Sulfida, bahan ini dihasilkan dari serbuk keramik. Biasanya Cadium Sulfida disebut juga bahan photoconductive, apabila konduktivitas atau resistansi dari Cadium Sulfida bervariasi terhadap intensitas cahaya. Jika intensitas cahaya yang diterima rendah maka hambatan juga akan tinggi yang mengakibatkan tengangan yang keluar juga akan tinggi begitu juga sebaliknya disinilah mekanisme proses perubahan cahaya menjadi listrik terjadi.[4]

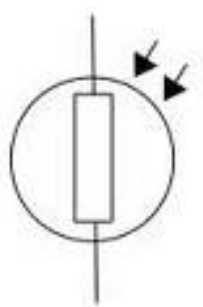

\section{Gambar 3. Simbol LDR}

\section{E. Liquid Crystal Display (LCD)}

Liquid Crystal Display (LCD) adalah suatu jenis media tampil yang menggunakan kristal cair sebagai penampil utama. LCD sudah digunakan diberbagai bidang misalnya alal-alat elektronik seperti televisi, kalkulator, ataupun layar komputer. Pada bab ini aplikasi LCD yang digunakan ialah LCD dot matrik dengan jumlah karakter 4x20.

LCD sangat berfungsi sebagai penampil yang nantinya akan digunakan untuk menampilkan status kerja alat.

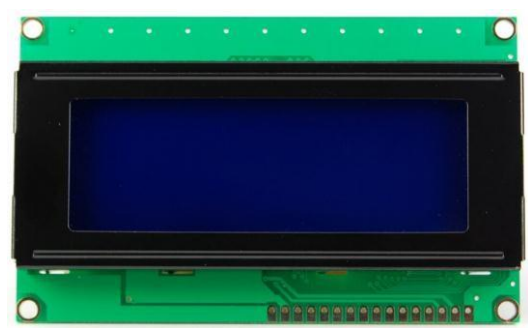

Gambar 4. Bentuk fisik LCD

\section{F. CodeVision AVR}

Menurut Desnanjaya et al, (2013) CodeVision AVR merupakan sebuah software yang dipergunakan untuk memprogram mikrokontroler. Pengembangan sebuah sistem menggunakan mikrokontroler CodeVision AVR merupakan software $C$-cross compiler, dimana program dapat ditulis dalam bahasa $\mathrm{C}$, CodeVision memiliki IDE (Integrated Development Environment) yang lengkap, dimana penulisan program, compile, link, pembuatan kode mesin (assembler) dan download program ke Chip AVR dapat dilakukan 
pada CodeVison AVR.

G. Arduino IDE

Microsoft Access atau Microsoft Office Access adalah sebuah program aplikasi basisdata computer relasional yang digunakan untuk merancang, membuat dan mengolah berbagai jenis data dengan kapasitas yang besar. Basisdata merupakan kumpulan dari tabel-tabel yang saling berelasi antar tabel yang satu dengan tabel yang lain, sehingga sering disebut basisdata relasional.

\section{METODE PENELITIAN}

A. Perancangan alat

Perancangan alat diawali dengan pembuatan diagram blok yang digunakan sebagai acuan untuk mengetahui konsep dari alat pendeteksi kondisi telur ayam berbasis mikrokontroler ATmega 32.

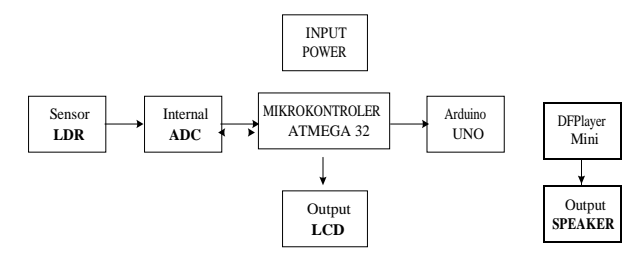

Gambar 5. Diagram blok perancangan alat

B. Perancangan Perangkat Keras

Adapun peranngkat keras yang disiapkan dalam perancangan alat pendeteksi kondisi telur ayam berbasis mikrokontroler ATmega 32 yaitu:

1. Rangkaian Minimum Sistem Mikrokontroler ATmega 32

Pada tugas akhir ini digunakan mikrokontroler ATmega 32 sebagai modul pengontrol utama. Mikrokontroler ATmega 32 memiliki 4 buah port I/O dimana port A difungsikan sebagai input yang menghubungkan sensor cahaya ke mikrokontroler ATmega 32 yang menggunakan fitur ADC, port $\mathrm{B}$ difungsikan untuk komunikasi dual mikro antara ATmega 32 dengan Arduino Uno, port C difungsikan sebagai input saklar untuk tombol ready atau siap mendeteksi kondisi telur ayam, dan port $\mathrm{D}$ difungsikan sebagai output yang mengolah data dari mikrokontroler kemudian ditampilkan dalam bentuk teks pada LCD (Liquid Crystal Display).

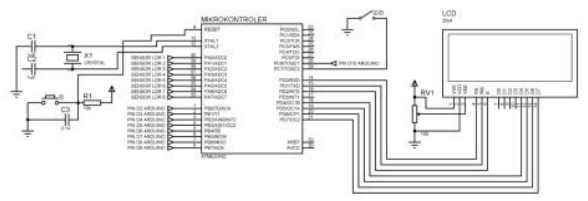

Gambar 6. Rangkaian utama ATmega 32

2. Rangkaian Minimum Sistem Arduino Uno Arduino Uno berfungsi untuk membantu kinerja dari mikrokontroler ATmega 32 dalam mengolah data dari masukan sensor yang akan ditampilkan dalam bentuk suara pada speaker.

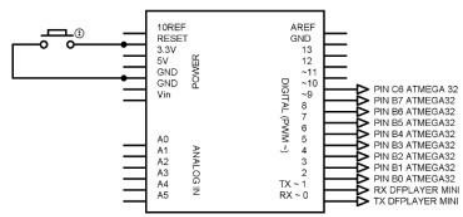

Gambar 7. Rangkaian Arduino Uno

\section{Rangkaian Sensor Cahaya}

Sensor cahaya berfungsi sebagai input data yang diolah oleh mikrokontroler. Dalam rangkaian ini sensor yang digunakan adalah sensor LDR (Light Dependent Resistor), sensor ini berfungsi untuk mendeteksi kondisi telur dengan mengetahui intensitas cahaya yang diterima. Pada pengaplikasiannya sensor ini

dihubungkan ke port A sebagai input pada mikrokontroler.

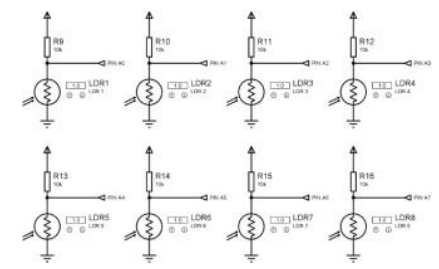

Gambar 8. Rangkaian sensor cahaya

\section{Rangkaian LCD (Liquid Crystal Display)}

Rangkaian LCD berfungsi untuk menampilkan hasil pengolahan data dari sensor cahaya ke mikrokontroler untuk ditampilkan, hasil tampilan dari LCD yaitu berupa teks. 


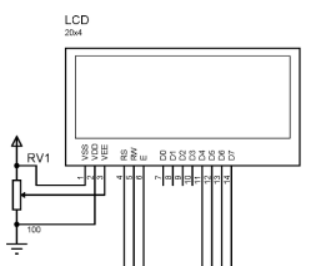

Gambar 9. Rangkaian LCD

5. Rangkaian DFPlayer Mini

Rangkaian DFPlayer mini berfungsi untuk mengolah data suara yang akan dikirim ke arduino uno kemudian diolah kembali oleh mikrokontroler ATmega 32 untuk dikeluarkan melalui speaker.

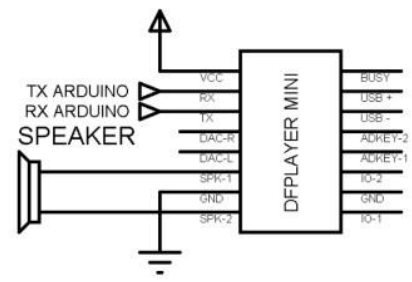

Gambar 10. Rangkaian DFPlayer mini

6. Rangkaian LED (Light Emitting Diode)

Rangkaian LED berfungsi sebagai sumber cahaya yang akan di terima oleh sensor LDR pada saat menentukan kondisi telur ayam kemudian akan diolah oleh mikrokontroler.

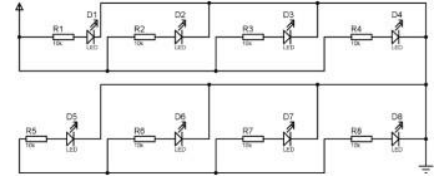

Gambar 11. Rangkaian LED

C. Perancangan Perangkat Lunak

Pada perancangan tugas akhir ini perangkat lunak yang digunakan yaitu:

\section{Perancangan program dengan Codevision} AVR

Codevision AVR digunakan untuk menuliskan kode perintah atau sintaks yang dijadikan sebagai prosedur pada mikrokontroler yang digunakan.

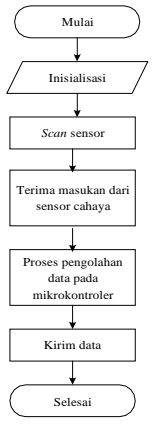

\section{Gambar 12. Flowchart prosedur kerja} mikrokontroler

2. Perancangan program dengan arduino IDE Arduino IDE digunakan untuk menuliskan kode perintah atau sintaks yang dijadikan sebagai prosedur pada arduino uno yang digunakan.

D. Pengujian hardware dan software

Proses pengujian hardware dan software merupakan proses akhir dari perancangan skripsi ini. Pengujian hardware dan software dilakukan secara bertahap diawali denga pengujian kinerja masing-masing hardware. Pengujian hardware dilakukan dengan cara mengukur dan mengamati perubahan keluaran rangkaian berdasarkan masukan yang diberikan. Selanjutnya dilanjutkan dengan pengujian software. Pengujian software dimulai dengan pengujian konektifitas port $\mathrm{I} / \mathrm{O}$ setelah perangkat dapat terhubung dengan baik, dilakukan pemrograman.

E. Analisis hasil pengujian

Analisa hasil pengujian merupakan tahapan mengidentifikasi hasil pengujian yang diperoleh untuk diuji kebenaran dan kesesuaiannya dengan teori-teori penunjang pembuatan skripsi.

\section{HASIL DAN PEMBAHASAN}

A. Bentuk Alat dan Penempatan Sensor

Desain alat yang dibuat adalah desain miniatur alat pendeteksi kondisi telur ayam yang mampu melakukan pengujian 8 butir telur ayam sekali uji. Desain miniatur alat ini terdiri dari 8 bagian pendeteksi yang dipasangi masing-masing sensor LDR.

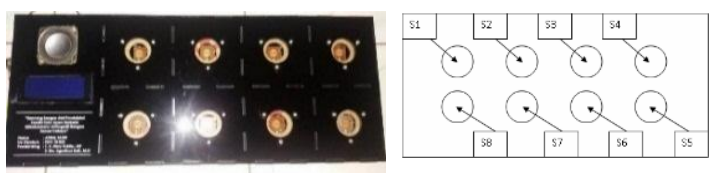

Gambar 13. Bentuk fisik alat

B. Minimum sistem ATmega 32

Minimum sistem ATmega 32 merupakan mikrokontroler utama yang berfungsi untuk mengontrol seluruh sistem yang ada pada perancangan ini, dengan VCC sebesar 5 Volt DC yang terintegrasi dengan Arduino Uno yang berfungsi untuk menghubungkan DFplayer mini 
agar mampu mengeluarkan output suara. Kemudian input utama dari perancangan ini yaitu sensor LDR.

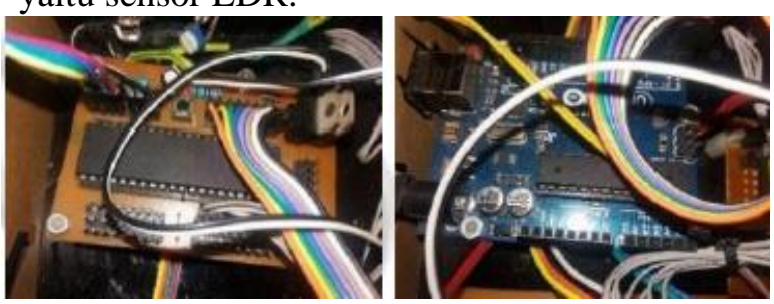

Gambar 14. Minimum sistem ATmega 32 dan Arduino Uno

C. DFPlayer mini dan speaker

DFplayer mini sebagai pengontrol suara yang berfungsi untuk mengontrol output suara pada perancangan pendeteksi kondisi telur ayam ini yang dapat didengarkan melalui speaker.
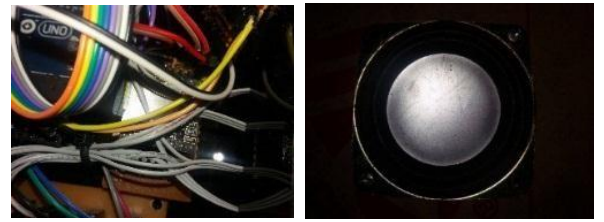

Gambar 15. Bentuk fisik DFPlayer mini dan speaker

\section{Sensor LDR}

Sensor LDR sebagai sensor yang berfungsi untuk mengetahui bagus atau rusaknya kondisi telur ayam yang dapat dilihat melalui output tampilan pada LCD dan output suara pada speaker.

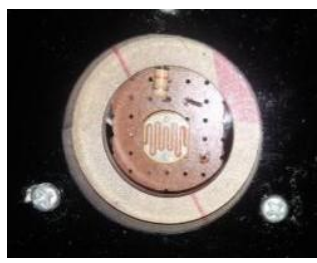

Gambar 16. Bentuk fisik sensor LDR

\section{E. LCD (Liquid Crystal Display)}

LCD sebagai media output pada penelitian ini yang berfungsi untuk menampilkan hasil pembacaan sensor LDR. Adapun hasil pembacaan sensor LDR yang ditampilkan pada LCD sebagai berikut.

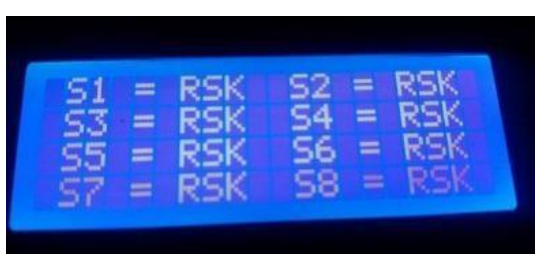

Gambar 17. Tampilan hasil pembacaan sensor LDR

F. Power Supply

Power supply sebagai sumber tegangan utama yang berfungsi untuk men-supply tegangan kesemua rangkaian yang ada pada alat pendeteksi kondisi telur ayam ini.
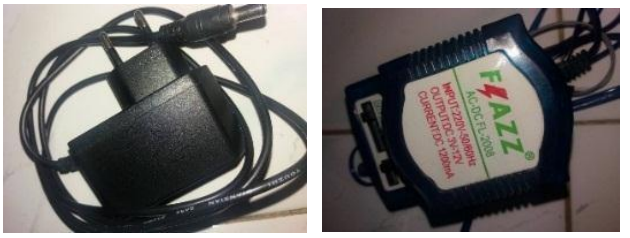

Gambar 18. Bentuk fisik power supply

\section{G. Prinsip Kerja}

Rancang bangun pendeteksi kondisi telur ayam berbasis mikrokontroler ATmega 32 terdiri dari 2 buah mikrokontroler dan 8 buah sensor LDR dibagian pendeteksi kondisi telur ayam. Di dalamnya terdapat beberapa rangkaian yang saling terintegrasi yaitu Adaptor, sensor LDR, Minimum sistem ATmega 32, Arduino Uno, DFplayer mini, LCD, dan Saklar. Alat pendeteksi

kondisi telur ayam ini bekerja pada tegangan 5 VDC yang di supply dari adaptor. Pada alat ini terdapat 8 sensor LDR yang terhubung dengan port A mikrokontroler ATmega 32 sebagai media input data, DFplayer mini terhubung dengan $R X$ dan TX Arduino Uno, LCD terhubung dengan port D Mikrokontroler ATmega 32 dan Saklar berfungsi untuk on/off pendeteksian yang terhubung pin C7 Mikrokontroler ATmega 32.

Prinsip kerja alat pendeteksi kondisi telur ayam yaitu harus dipastikan semua adaptor terhubung ke alat, kemudian tekan tombol power (on/off) maka alat otomatis akan hidup dan LCD akan menampilkan "Selamat datang silahkan masukkan telur ayam" dan akan mengeluarkan suara. 


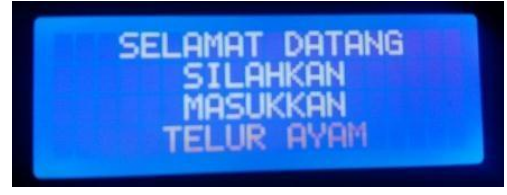

Gambar 19. Tampilan awal pada saat $\mathrm{ON}$

Setelah telur dimasukkan ke penempatan posisi sensor dan tudung LED ditutup kemudian tekan tombol ready maka sensor akan membaca kondisi telur ayam. Apabila ada salah satu atau beberapa telur rusak, maka sensor LDR akan mendeteksi satu persatu kondisi telur ayam dan hasil pembacaan sensor LDR akan ditampilkan pada LCD kemudian mengeluarkan sura pada speaker.

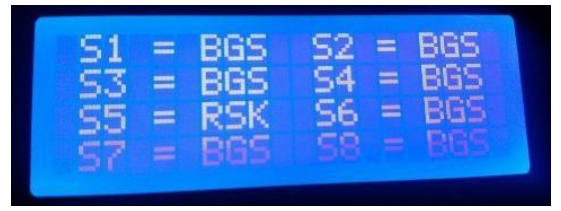

Gambar 20. Tampilan pada saat telur 5 rusak

Sedangkan jika semua telur dalam kondisi bagus, otomatis sensor LDR akan membaca secara keseluruhan dan hasil pembacaan sensor LDR akan ditampilkan pada LCD serta mengeluarkan suara "Semua Bagus", begitupun sebaliknya jika kondisi telur ayam secara keseluruhan rusak, maka sensor LDR akan membaca secara keseluruhan dan mengeluarkan suara pada speaker "Semua Rusak".

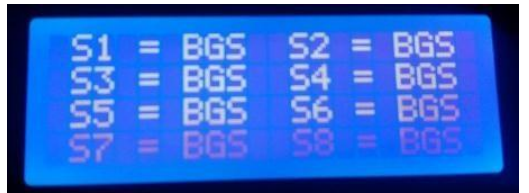

Gambar 21. Tampilan pada saat semua telur bagus

Alat pendeteksi kondisi telur ayam ini memanfaatkan cahaya LED yang telah dirangkai secara parallel dan sensor LDR akan menerima cahaya yang menembus cangkang telur, dari data hasil pendeteksian sensor LDR telah di dapatkan nilai ADC 10 bit untuk menentukan kondisi telur ayam yang baik maupun rusak.

\section{H. Analisis software}

Pada rancang bangun pendeteksi kondisi telur ayam berbasis mikrokontroler ATmega 32 dengan sensor cahaya, software merupakan bagian penting yang tidak dapat dipisahkan dari perangkat keras (hardware). Tanpa software yang berisi sekumpulan data digital untuk mengendalikan hardware, perangkat ini tidak dapat dioperasikan.

Pada perencangan ini ada 2 jenis perangkat lunak yang dibangun untuk mengendalikan perangkat keras yaitu perangkat lunak yang digunakan mengendalikan mikrokontroler yang dibuat dengan bahasa $\mathrm{C}$ menggunakan aplikasi pemrograman CodeVision AVR dan Arduino IDE.

\section{PENUTUP}

\section{A. Kesimpulan}

Rancang bangun alat pendeteksi kondisi telur ayam berbasis mikrokontroler ATmega 32 dengan sensor cahaya yang dirancang melakukan komunikasi dual mikro dari mikrokontroler ATmega 32 dan Arduino Uno secara otomatis saat sistem beroperasi. Pendeteksi kondisi telur ayam terdiri dari sensor LDR sebagai sensor pendeteksi kondisi telur ayam, LED sebagai sumber cahaya untuk pendeteksian kondisi telur ayam, mikrokontroler sebagai pemroses data, LCD sebagai media output tampilan, Speaker sebagai media output suara dan DFplayer mini sebagai pengontrol suara, sehingga alat pendeteksi kondisi telur ayam untuk penyortiran

dan pemisahan kondisi telur ayam bisa lebih optimal dan efisien.

Alat pendeteksi kondisi telur ayam memanfaatkan cahaya LED dan sensor LDR untuk melakukan pendeteksian kondisi telur ayam, sistem pendeteksi kondisi telur ayam ini mampu melakukan penyortiran 8 butir telur dalam sekali pengujian. Dari hasil pengujian alat secara keseluruhan, waktu pembacaan alat berbeda ketika ada salah satu kondisi telur ayam yang rusak, waktu pembacaan akan lebih lama dibandingkan pada saat kondisi telur ayam sumua bagus atau semua rusak dikarenakan sensor LDR akan menguji telur ayam satu per satu. 


\section{DAFTAR PUSTAKA}

[1] Falahuddin, Anas. 2015. Mikrokontroler Atmega 32 , http://www.anasfalahuddin.tk/2015/01/mikr okontroler-atmega32.html, diakses 27 Januari 2016.

[2] Taufik, Azzi. 2014. Mikrokontroler Arduino Uno,

http://dialogsimponi.blogspot.co.uk/2014/1 1/normal-0-false-false-false-in-x-nonex.html, diakses 29 Januari 2016.

[3] Anonim. 2013. Petunjuk Modul Praktikum Elektronika Digital 2 Analog to Digital Converter, http://prima.lecturer.pens.ac.id/ElkaDigiS2 Modul11.pdf, diakses 25 November 2016.

[4] Prastyo, Elga Aris. 2013 LDR (Light Dependet Resistor),http://www.edukasielektronika.co $\mathrm{m} / 2013 / 0 \quad 2 /$ ldr-light-dependentresistor.html, diakses 29 Januari 2016. 